Data Fabrication in Accounting and Business Studies:

A Legal Approach

F. E. Guerra-Pujol

University of Central Florida

fegp@ucf.edu 


\title{
Data Fabrication in Accounting and Business Studies: \\ A Legal Approach
}

\begin{abstract}
The general problem of research fraud by accounting and business researchers has received significant scholarly attention of late. Most of the descriptive work on data fraud is concerned with diagnosing the causes of fraudulent and deceptive research practices or with measuring their extent, while on the normative side, most calls for reform in academic publishing rely largely on more rigorous data policies and renewed calls for observational awareness. Alas, it remains to be seen whether such methods of self-regulation will be effective at reducing the incidence of research fraud. This paper thus proposes a different approach to data fraud, one that is more likely to reduce the incidence of data fabrication. Specifically, I propose that alleged serial academic fraudsters like James Hunton be charged with criminal wire fraud. My previous work in this domain explored the possibility of imposing civil liability for data fraud committed by academic researchers. This paper, by contrast, will explore the possibility of criminal liability when an author knowingly fabricates data in his research.
\end{abstract}

\section{DISCLAIMER}

This is a working paper and hence represents research in progress. This paper presents the opinions of the author and is not meant to represent the positions of the University of Central Florida or of any of the participants of the Florida Accounting Symposium. Do not cite or circulate without the author's permission.

Keywords: Academic Fraud, Hunton, Wire Fraud

JEL Classification: K42, M49

Date: July 23, 2019 


\section{INTRODUCTION}

Although questionable research practices such as p-hacking and post hoc hypothesis testing (or HARKing) are allegedly quite common in many research fields, including academic accounting and business studies generally (see, e.g., Butler, et al., 2017), there is some controversy about the extent of outright data fraud or data fabrication (see, e.g., Martin, 2015). For instance, is the egregious example of disgraced accounting professor James E. Hunton a rare extreme outlier-one bad apple in an otherwise good barrel of research apples? Or is Dr. Hunton just the tip of a massive research fraud iceberg--the one academic accountant who was unlucky enough to get caught?

The general problem of research fraud has received significant scholarly attention of late (see, e.g., Grienensen and Zhang, 2012). Moreover, according to one scholar (Dennis Tourish), "the existing level of retractions [in business studies] is likely understate the level of research misconduct" (see Oransky, 2018). Most of the descriptive work on data fraud in academic accounting is concerned with diagnosing the causes of fraudulent and deceptive research practices or with measuring their extent (see, e.g., Bailey, 2015), while on the normative side, most calls for reform in academic publishing rely largely on more rigorous data policies, such as those adopted by the Journal of Accounting Research (2014/1016), and on renewed calls for observational awareness (see, e.g., Stone, 2015). For their part, Tourish and Craig (2018, pp. 1012), propose a plethora recommendations for reducing the incidence of data fraud and data deception (11 recommendations in all). Alas, their recommendations are addressed solely to authors, editors, and publishers, as well as to the "broader scientific community." (Ibid. at p. 12.) Given the incentive structure of academic publishing (see, e.g., Butler, et al., 2017), it remains to 
be seen whether such methods of self-regulation will be effective at reducing the future incidence of data fraud in such fields as accounting.

This paper thus proposes a different approach to fraudulent research, one that is more likely to reduce the incidence of data fabrication. With rare exceptions (see, e.g., Guerra-Pujol, 2017), the existing literature on data fraud and data fabrication views these bad practices through a purely ethical lens (see, e.g., Tourish \& Craig, 2018; Bailey, 2015). This paper, by contrast, will explore the possibility of criminal sanctions against academic researchers who fabricate data. My previous work in this domain explored the possibility of imposing various forms of tort and contract liability for data fraud committed by academic researchers. See Guerra-Pujol, 2017. Building on my previous work, I will explore the possibility of criminal liability when an author knowingly fabricates research data in a published paper. In a word, the fabrication of data--the attempt to publish fake data, to be more precise--should be treated as a crime.

The remainder of this normative paper is structured as follows: Section 2 revisits the recent case of one notorious serial academic fraudster, former accounting professor James Hunton, and explains why the measures taken by the American Accounting Association (AAA) and the Journal of Accounting Review (JAR) in response to Professor Hunton's alleged misconduct are unlikely to be effective. Section 3 summarizes the federal wire fraud statute, and Section 4 explains why the wire fraud law is sufficiently broad to include misconduct consisting of data fabrication, while Sections 5 and 6 explore the application of wire fraud to co-authors and journal editors and to lesser forms of data fraud, such as p-hacking and other questionable research practices. Section 7 concludes with a call to action: Hunton should be charged with the crime of wire fraud. 


\section{THE CASE OF JAMES HUNTON}

To motivate this paper, I will refer to the example of James E. Hunton, a former award-winning accounting professor whose entire body of work has now been called into question. See Malone, 2014. For a summary of Professor Hunton's alleged misdeeds, see Horton, et al. (2018, pp. 8-9), and for a complete compilation of Hunton's retracted papers, see Meckfessel and Moehrle (2017, table 2). Professor Hunton's case is emblematic of most cases of alleged fraudulent academic research: a few bad apples in a given field are responsible for the lion's share of retractions in that field (see, e.g., Dickens \& Schneider, 2016).

Should Professor Hunton be charged under the federal wire fraud statute? In summary, the first sign of trouble in the case of James Hunton was a vague, two-sentence retraction notice published in the online version of The Accounting Review in late 2012. (The published version of the retraction notice appears in Hunton \& Gold, 2013.) This initial retraction led to an 18-month investigation by Judith A. Malone, an ethics officer at Bentley University, Professor Hunton's home institution before his resignation in December of 2012. ${ }^{1}$ Malone uncovered a pattern of serious research misconduct and concluded (Malone, 2014, p. 5) that "[t]he whole body of Dr. Hunton's extensive research ... must now be considered suspect." Based on the findings of Malone's investigation, the American Accounting Association retracted an additional 25 papers published by Professor Hunton. See AAA, 2015. To date there have been 38 retraction notices issued on research papers published by Hunton as either a sole or co-author. See Meckfessel \& Moehrle, 2017, table 2.

\footnotetext{
${ }^{1}$ At the time of his resignation, Professor Hunton cited "family and health reasons." See Healy, 2012.
} 
The American Accounting Association also took additional actions to prevent future cases of research fraud. It established a Publication Ethics Task Force and assigned it the responsibility of developing new standards and policies governing plagiarism, data sharing, and the fabrication of data. In addition, some top-tier accounting journals now require additional assurances and disclosures from its authors. By way of example, the editors of the Journal of Accounting Research adopted and then updated a "data and code sharing policy," although this policy does not require authors to make their data publicly available. See JAR, 2014/2016.

How effective are these feeble methods likely to be? It remains to be seen whether such forms of self-regulation will stem the research fraud tide. To the extent these symbolic or spineless reforms rely on ethical constraints and self-policing, I am highly skeptical of their effectiveness. This paper thus proposes a different approach. In brief, if there is sufficient evidence to support the conclusion that Hunton submitted fabricated data to various accounting journals, then Hunton and other alleged serial academic fraudsters should be charged with the crime of wire fraud.

\section{THE FEDERAL WIRE FRAUD STATUTE AND RELATED CRIMES}

The federal wire fraud statute (18 US Code, Section 1343, as amended) is exceptionally broad and "has been invoked to impose criminal penalties upon a staggeringly broad swath of behavior." 2 The penalties for wire fraud can be severe: a term of imprisonment of up to 20 years,

\footnotetext{
2 Sorich v. United States, 555 U.S. 1204, 1205 (2009) (Scalia, J., dissenting), quoted in Doyle,
} 2019, p. 1. 
followed by a term of supervised release. In addition, convicted offenders also face the prospect of fines, orders to make restitution, and forfeitures of their property. ${ }^{3}$

As an historical aside, wire fraud is closely related to the federal offense of mail fraud (18 US Code, Section 1341, as amended), which proscribes any fraudulent scheme committed with the use of the U.S. mail or other interstate carriers. The U.S. Congress enacted the first mail fraud statute in 1872 and then enacted a companion wire fraud statute eighty years later (1952) in order to extend the prohibitions on mail fraud to newer communications technologies, and courts have generally held that wire fraud is identical to mail fraud under federal law, except for the means of communication used. ${ }^{4}$ Also, in the leading case of McNally v. United States, 483 U.S. 350 (1987), the U.S. Supreme Court held that the mail fraud statute--and, by implication, the wire fraud statute as well--applies to any act "designed to defraud by representations as to the past or present, or suggestions and promises as to the future." 5

In addition, some State criminal codes may also contain specific provisions that are applicable to acts of wire fraud. By way of example, Section 502(c)(1) of the California Penal Code makes it unlawful for any person to "[k]nowingly access[] and without permission alter[], damage[], delete[], destroy[], or otherwise use[] any data, computer, computer system, or computer network in order to either devise or execute any scheme or artifice to defraud, deceive, or extort, or wrongfully control or obtain money, property, or data." ${ }^{96}$ The language of the federal

\footnotetext{
${ }^{3}$ The text of the federal wire fraud statute is set forth in the Appendix to this paper. For an excellent overview of the federal wire and mail fraud statutes as well as the leading cases, see Doyle, 2019.

${ }^{4}$ See, e.g., United States v. Frey, 42 F.3d 795 (3d Cir. 1994).

${ }^{5}$ McNally, 483 U.S. at p. 357, quoting Durland v. United States, 161 U. S. 306, 313 (1896).

${ }^{6}$ Section 502 of the California Penal Code is available at https://codes.findlaw.com/ca/penalcode/pen-sect-502.html (last visited on July 23, 2019).
} 
wire fraud statute, by contrast, is more general and broad, so the focus of the remainder of this paper will be on the federal crime of wire fraud.

\section{DATA FABRICATION AS CRIMINAL WIRE FRAUD}

It is generally up to State and federal prosecutors to decide what charges to bring and how to pursue each case; when prosecutors decline to a bring a criminal case, this exercise of authority is referred to as "prosecutorial discretion" (see, e.g., Bibas 2010; Melilli, 1992). The practice of prosecutorial discretion, however, poses an intriguing question in the context of research fraud. Although federal prosecutors have charged researchers for making false statements on federal research grant applications, ${ }^{7}$ they have yet to charge serial academic fraudsters like James Hunton or Diederik Stapel with wire fraud. Why not? This paper will invite federal prosecutors to reconsider their excerise of prosecutorial discretion in the domain of research fraud, for it is beyond question that the outright fabrication of data--like the research misconduct that Hunton is alleged to have committed--not only calls into question the integrity of academic accounting; a strong case can also be made that fraudulent research constitutes the crime of wire fraud.

In summary, wire fraud is a criminal offense under federal law. Wire fraud involves any scheme to defraud another person that uses electronic communications, either across State lines or internationally. Moreover, although the federal wire fraud statute specifically mentions wire, radio, and television communications, courts and prosecutors have interpreted the scope of the

\footnotetext{
${ }^{7}$ At least one scientific researcher, Doug Pyou Han, who was affiliated with Iowa State University, was charged in 2014 by federal prosecutors with making false statements to procure a research grant from the National Institutes of Health (see Dyer, 2014). Dr. Han pled guilty to making false statements and was sentenced to 57 months in federal prison on July 1, 2015. See USAO, 2015. Note that the crime of making false statements (18 US Code, Section 1001) is a different crime than wire fraud (18 US Code, Section 1343). This paper will focus on wire fraud.
} 
wire fraud statute broadly to includes any scheme to defraud involving computers and the Internet (see, e.g., Rodriguez, 2015). Also, since a key element in criminal wire fraud cases is the means by which fraudulent statements are transmitted, the crime of wire fraud includes almost any type of fraudulent scheme, including bank fraud, tax fraud, and insurance fraud. See Doyle, 2019, pp. 20-28.

Specifically, in the context of fraudulent academic research, the prosecution would have to prove the following legal elements beyond a reasonable doubt in order to obtain a conviction for wire fraud:

(1) Scheme to obtain something of value: the researcher must be part of a scheme to defraud another person, such as by obtaining money or something else of value through false pretenses;

(2) Intent: the researcher must have acted knowingly or with the intent to defraud when he use the fake data;

(3) Materiality: the researcher must have made false representations that were material to his scheme; and

(4) Transmission: the researcher must have transmitted a material misrepresentation or misstatement (i.e. his fabricated data) by wire, radio, or television communications in interstate or foreign commerce. ${ }^{8}$

All four of these essential elements could potentially be met in cases involving data fabrication and other forms of research fraud: scheme to obtain something of value, intent, materiality, and transmission. As an aside, I will consider separately below the problem of

\footnotetext{
8 This element is the "jurisdiction hook" of the wire fraud statute, i.e. what authorizes the Congress to make wire fraud a federal crime.
} 
“innocent" co-authors and journal editors under the wire fraud statute (Section V; cf. McCook, 2018) and whether the wire fraud law applies to lesser but more common forms of research fraud, such as p-hacking, HARKing, self-plagiarism etc. (Section VI).

Scheme to obtain something of value. The first legal element requires a scheme to defraud in order to obtain money or "something of value." As a result, this element would be met in cases of fabricated research data only if the researcher were attempting to obtain a research grant, a scholarly publication, or something else of value. Courts, however, have ruled that the "something of value" (whatever it is) must have value to victim of the scheme, ${ }^{9}$ so it is an open question whether a research publication, standing alone, would count as something of value under the wire fraud statute. Nevertheless, one could argue that the direct victims of fabricated data--in particular, journals and innocent co-authors--have a property interest in their publications. Also, although academic authors do not generally receive direct compensation for their scholarly publications, their academic careers often depend on their ability to publish in respected academic journals.

Intent to defraud. The second element, intent, is often referred to as scienter in the case law. How does one prove intent? Is the use of fake data, by itself, sufficient to infer a "intent to defraud" one's co-authors, journal editors, and the larger academic community? If so, a prosecutor would only have to prove that a researcher's data was fabricated and that the researcher knew that the data was fake or doctored in some significant way. To the extent the researcher's co-authors and journal editors are the direct victims of his research fraud, the scienter requirement would most likely protect such innocent co-authors and journal editors from

${ }^{9}$ See, e.g., Cleveland v. United States, 531 U.S. 12 (2000). 
a wire fraud prosecution. (I will explore the possibility of criminal liability of co-authors and journal editors for wire fraud in Section V below.)

Materiality. Courts have read a materiality requirement into the federal mail and wire fraud statutes. ${ }^{10}$ That said, who can doubt whether the use of fabricated data would constitute a material misrepresentation for purpose of proving wire fraud, since the integrity of a researcher's data is always going to be material to the decision whether to publish the author's work? At the same time, it is an open question whether lesser forms of data fraud such as p-hacking would constitute a material misrepresentation. (I will explore the possibility of criminal liability for lesser forms of research fraud or so-called "questionable research practices" in Section VI below.)

Transmission. Given that most scholarly journals utilize electronic submission systems, the fourth essential element of wire fraud would be the easiest to meet in the context of research fraud. Furthermore, it's worth noting that a person may be found guilty of wire fraud even if he did not personally send a fraudulent transmission. The prosecution must only prove that the defendant either (i) intended to defraud someone or (ii) acted with knowledge that wire communications were being used to transmit fraudulent representations. In the leading case of Pereira v. United States, 347 U.S. 1 (1954), for example, the U.S. Supreme Court held that, even if a defendant did not intend the specific transmission, he could still be convicted of wire fraud if the transmission was reasonably foreseeable "in the ordinary course of business."11

\footnotetext{
${ }^{10}$ See, e.g., Neder v. United States, 527 U.S. 1 (1999).

${ }^{11}$ Pereira, 347 U.S. at p. 8.
} 


\section{CRIMINAL LIABILITY OF CO-AUTHORS AND EDITORS?}

[This section will explore the potential liability of innocent co-authors and journal editors under the wire fraud statute and will be added at a later date, but before the Florida Accounting Symposium scheduled for September 13-14, 2019 at the University of Florida, Warrington College of Business.]

\section{CRIMINAL LIABILITY FOR LESSER FORMS OF DATA FRAUD?}

[This section will explore whether the wire fraud statute could apply to lessor forms of data fraud and will be added at a later date, but before the Florida Accounting Symposium referred to above.]

\section{CONCLUSION}

Some business and accounting journals have adopted new and more rigorous data policies, such as those recently adopted by the Journal of Accounting (Editors of JAR, 2014/2016). Similarly, some accounting scholars have called for new "contemplative practices" and "observational awareness" (Stone, 2015), while others have called for the adoption of clear language, such as use of the phrase "deceptive research practices" in place of "questionable research practices" (Tourish \& Craig, 2018, p. 12). I, however, remain skeptical of the efficacy of such feeble measures. Mere words, contemplation, and data policies that do not call for the disclosure of data will be ineffective in reducing the incidence of research fraud given the perverse "publish or perish" incentive structure of academia. Instead, serial academic fraudsters like James Hunton and others should be prosecuted for wire fraud to the full extent of the law. 


\section{APPENDIX}

The relevant text of the federal wire fraud statute (18 US Code, Section 1343, as amended) states: "Whoever, having devised or intending to devise any scheme or artifice to defraud, or for obtaining money or property by means of false or fraudulent pretenses, representations, or promises, transmits or causes to be transmitted by means of wire, radio, or television communication in interstate or foreign commerce, any writings, signs, signals, pictures, or sounds for the purpose of executing such scheme or artifice, shall be fined under this title or imprisoned not more than 20 years, or both. If the violation occurs in relation to, or involving any benefit authorized, transported, transmitted, transferred, disbursed, or paid in connection with, a presidentially declared major disaster or emergency ..., or affects a financial institution, such person shall be fined not more than $\$ 1,000,000$ or imprisoned not more than 30 years, or both." 


\section{REFERENCES}

American Accounting Association (AAA). 2015. Retraction of articles related to James E. Hunton. AAA press release, available at http://aaahq.org/Portals/0/documents/WebsiteFinalListofRetractedArticles-6-25-15.pdf (last visited on July 23, 2019).

Bailey, Charles D. 2015. Psychopathy, academic accountants' attitudes toward unethical research practices, and publication success. The Accounting Review, 90(4): 1307-1332.

Bibas, Stephanos. 2010. The need for prosecutorial discretion. Temple Civil and Political Rights Law Review, 19(2): 369-375.

Butler, Nick, Helen Delaney, and Sverre Spoelstra. 2017. The grey zone: questionable research practices in the business school. Academy of Management Learning \& Education, 16: 94-109.

Doyle, Charles. 2019. Mail and wire fraud: a brief overview of federal criminal law. Congressional Research Service, CRS Report No. R41930 (Version 8), available at https://fas.org/sgp/crs/misc/R41930.pdf (last visited on July 23, 2019).

Dyer, Owen. 2014. Researcher is arrested for falsifying his results. BMJ 2014, 348: g4249, available at https://www.bmj.com/content/bmj/348/bmj.g4249.full.pdf (last visited on July 23, 2019).

Dickens, Denise, and Douglas K. Schneider. 2016. Academic research in accounting: a framework for quality reviews. Current Issues in Auditing, 10(1): A34-A46.

Editors of the Journal of Accounting Research (JAR). 2014/2016. Data and Code Sharing Policy. Journal of Accounting Research, available at https://research.chicagobooth.edu//media/research/arc/docs/journal/updated-data-policy-forjar.pdf?la=en\&hash=CD1D669E679E9649CEA9F89948F616E84989DEE4 (last visited on July 23, 2019).

Guerra-Pujol, F. E. 2017. Legal liability for data fraud. Statistical Journal of the IAOS, 33(3): 755-761.

Healy, Beth. 2012. Bentley professor resigns after his research is retracted. The Boston Globe (Dec. 12, 2012), available at https://www.bostonglobe.com/business/2012/12/21/bentleyaccounting-professor-james-hunton-amid-controversy-over-retractionresigns/y4JtNvlr1SwNnFcpBFcY4J/story.html (last visited on July 23, 2019).

Horton, Joanne, Dhanya Krishnakumar, and Anthony Wood. 2018. Detecting academic fraud in accounting research: the case of Professor James Hunton. SSRN working paper, available at https://papers.ssrn.com/sol3/papers.cfm?abstract_id=3164961 (last visited on July 23, 2019).

Grienensen, Michael L. and Minghua Zhang. 2012. A comprehensive survey of retracted articles from the scholarly literature. PLoS One, 7(10): e44118, available at 
https://journals.plos.org/plosone/article?id=10.1371/journal.pone.0044118 (last visited on July $23,2019)$.

Hunton, James E., and Anna Gold. 2013. Retraction: a field experiment comparing the outcomes of three fraud brainstorming procedures: nominal group, round robin, and open discussion. The Accounting Review, 88(1): 357-357, available at https://aaajournals.org/doi/abs/10.2308/accr10326 (last visited on July 23, 2019).

Malone, Judith A. 2014. Report of Judith A. Malone, Bentley University ethics officer, concerning Dr. James E. Hunton. Bentley University, available at https://aaajournals.org/doi/supp1/10.2308/accr-

10435/suppl_file/bentley+report+republish+permission.pdf (last visited on July 23, 2019).

Martin, Alan. 2015. The elephant in the lab: how much science is fabricated? Alphr, available at http:/www.alphr.com /science/1001618/the-elephant-in-the-lab-how-much-science -is-fabricated (last visited on July 23, 2019).

Klinefeldt, Nicholas A. 2015. Former Iowa State researcher pleads guilty to making false statements. DOJ press release, available at https://www.justice.gov/sites/default/files/usaosdia/legacy/2015/02/25/Han\%20-\%20Plea\%202-\%2025-15.pdf (last visited on July 23, 2019).

McCook, Allison. 2018. Fallout for co-authors. Science, 362(6413): 394-395.

Meckfessel, Michele, and Stephen Moehrle. 2017. Self-regulation of the academic accounting literature: the case of James Hunton. Research in Accounting Regulation, 29(1): pp. 10-18.

Melilli, Kenneth J. 1992. Prosecutorial discretion in an adversary system. BYU Law Review, 1992(3): 669-704.

Oransky, Ivan. 2018. Legal threats, opacity, and deceptive research practices: a look at more than 100 retractions in business and management. Retraction Watch (interview of Dennis Tourish dated November 23, 2018), available at https://retractionwatch.com/2018/11/23/legal-threatsopacity-and-deceptive-research-practices-a-look-at-more-than-100-retractions-in-business-andmanagement/ (last visited on July 23, 2019).

Rodriguez, Diego. 2015. Nine people charged in largest known computer hacking and securities fraud scheme. DOJ press release, available at: https://www.fbi.gov/contact-us/fieldoffices/newyork/news/press-releases/nine-people-charged-in-largest-known-computer-hackingand-securities-fraud-scheme (last visited on July 23, 2019).

Stone, Dan N. 2015. Post-Hunton: reclaiming our integrity and literature. Journal of Information Systems, 29(2): 211-227.

Tourish, Dennis, and Russell Craig. 2018. Research misconduct in business and management studies: causes, consequences, and possible remedies. Journal of Management Inquiry, available 
at https://journals.sagepub.com/doi/pdf/10.1177/1056492618792621 (last visited on July 23, 2019).

Word count: 3919 words, excluding footnotes 